\title{
Globalisation and Glocalisation of the Slovak LANGUAGE IN THE EURopean UNion
}

\author{
Ol'ga ŠKVARENINOVÁ, Trnava*
}

\section{Content}

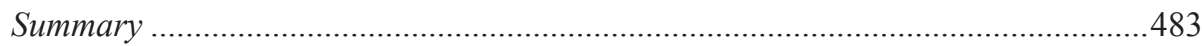

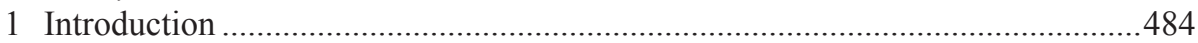

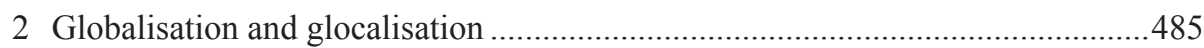

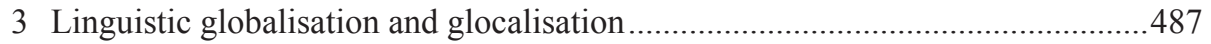

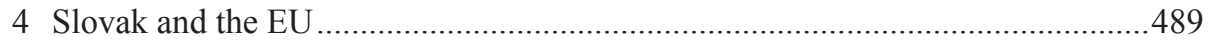

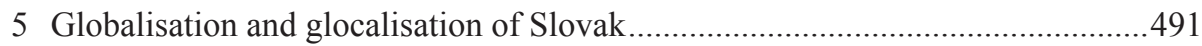

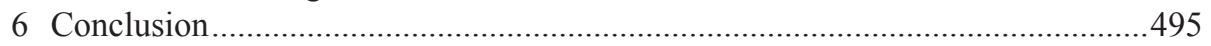

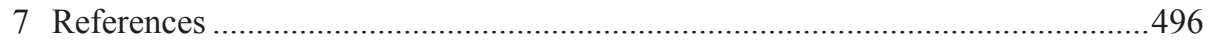

\section{Summary}

The paper deals with the co-existence of Slovak with other languages in the European Union (EU) and focuses on language dynamics, actualisation, domestication and lexicographical unification. With examples taken from English, the lingua franca of globalisation, it investigates the degree of Slovak language globalisation and glocalisation. Linguistic globalisation is understood herein as the penetration of new linguistic elements from a donor language on all linguistic levels. Linguistic glocalisation is understood as the adaptation of new linguistic elements into the internal linguistic system of the receiving language, and as the ability of a language to connect international and global elements with original domestic ones. Linguistic glocalisation requires the co-existence and upholding of two basic linguistic principles: (1) the principle of the linguistic stability of the 'local' language, which will secure its

* Ol'ga ŠKvareninová, Assist. Prof. PhD., Faculty of Mass Media Communication, University of Ss. Cyril and Methosius, Nám. J. Herdu 2, 91701 Trnava, Slovakia; email: olga. skvareninova@ucm.sk, http://fmk.sk/profil/olga-skvareninova/ 
future development; and (2) the principle of linguistic freedom, which will allow the language user to choose from a range of alternatives.

The globalising influence of English on Slovak emphatically appeared from the 1990s. This influence continued after the entry of Slovakia into the EU, when Anglicisms connected to the integration of European countries and the unification of rights and legislation within EU member states were introduced into the Slovak language. In this sense, it is necessary to underline that Slovak has always been internally prepared to accept external linguistic influences and adapt them to its own linguistic system. Furthermore, the degree of adaptation of external linguistic elements is directly related to the level of their linguistic globalisation or glocalisation. Anglicisms in Slovak are initially written in their original English form (linguistic globalisation), but subsequently most Anglicisms acquire variations in spelling (linguistic globalisation and glocalisation). Eventually Anglicisms are only written in accordance with their pronunciation in Slovak (linguistic glocalisation). The globalisation and glocalisation of Slovak can also be seen in the use of compound nouns and multiword naming units, many of which are literal calques from English, and in the use of hybrid polylexical set expressions and structures, which are taken and translated from English.

This paper asserts that the globalisation and glocalisation of Slovak does not bring about any tension between the local and the global. Glocalisation is seen as the adaptation of Anglicisms into the Slovak linguistic system, which is not a new process from a diachronic point of view. The usage of hybrid glocalising linguistic elements is proof of the tendency to make communication more attractive, make a striking impression, and to come across as colloquial, fun, emotional and younger.

\section{Introduction}

Within Indo-European languages, Slovak (along with Czech, Polish, Lusatian Sorb and Kashubian) is categorised as a West-Slavic language. "The linguistic, historical and archaeological facts show that Slovak developed directly from ProtoSlavic (without passing through a stage of Proto-Czechoslovak). The Proto-Slavic foundation of the Slovak language developed in the region between the Carpathian Mountains, the Danube River and the lower Morava River. This region was in contact with the West-Slavic area to the west and with the East-Slavic area to the north and north-east. The area was settled by Slavs, the ancestors of the Slovaks, who came from the south-east in the $6^{\text {th }}$ century. The reconstructed language of the Great Moravian ethnic group (from the $9^{\text {th }}$ century) can be considered as the basis of Slovak." (Mistrík 1993, p. 339) From the $10^{\text {th }}$ century, the Slovak language developed independently, similarly to other West Slavic languages. Its form stabilised between the $13^{\text {th }}$ and the $15^{\text {th }}$ centuries. The process of the codification of standard literary Slovak began in the late $18^{\text {th }}$ century. When taking into account the creation and operation of the standard 
literary language, it is clear that Slovak has developed independently and has nimbly reacted to communicative needs at a social and individual level.

In the present day, Slovak has all the attributes of a refined language, whereby "standard Slovak is considered to be the most important, distinguished and highest form of the national language in hierarchical terms" (Ministry of Culture of the Slovak Republic). Standard Slovak is used nationwide, and its form is guaranteed by codification. Use of the codified language is mandatory in the different areas of public life across the country. The authority of codified Slovak is managed by the Ministry of Culture of the Slovak Republic, which is the government body responsible for language policy and the regulation of Slovak. The ministry is guided by the expert opinions of research institutes (especially that of the L'udovít Štúr Institute of Linguistics at the Slovak Academy of Sciences) when making decisions on linguistic matters.

Currently, in Slovakia there are four primary codification manuals, which vary in content and which are applicable to certain areas of the usage of codified Slovak. They are Pravidlá slovenského pravopisu (Rules of Slovak Spelling), which is used for the purposes of correct writing; Pravidlá slovenskej výslovnosti (Rules of Slovak Pronunciation), used for correct pronunciation; Krátky slovník slovenského jazyka (Short Dictionary of the Slovak Language), used for vocabulary; and Morfológia slovenského jazyka (Morphology of the Slovak Language), which is used for word formation (conjugation and declension). Of the above texts, the most widely used are Rules of Slovak Spelling and the Short Dictionary of the Slovak Language.

\section{Globalisation and glocalisation}

According to the Oxford English Dictionary, the term globalisation was first used in 1930 by BoYD \& MACKENZIE in "Toward New Education" as a means of holistically perceiving people's experiences in education. The authors of the Slovak publication Vel'ký slovník cudzích slov (Big Dictionary of Foreign Words) also defined the term in an educational manner as "a pedagogical approach, which in the teaching process is based upon wholeness and natural situations, thus preserving 'the entirety of life until an individual comes to analyse it as a means of natural development" (ŠALING, Ivanová-ŠAlingová \& Maníková 1997a, p. 443). From 1972 the term globalisation began to be used in relation to the increasing power and dominance of multinational giants. In 1983 the term was popularised by LeviTT, who first used it in relation to the economy.

In the present day, globalisation is discussed as an economic term and is used in a broader sense as denoting a process of growing global interconnection in all areas (e.g. the economy, culture, politics, the environment, education and communication) as well as in the sense of the "concentration and unification of something on a global 
level" (Š́aling, Ivanová-ŠAlingová \& Maníková 1997b, p. 218). In the Oxford English Dictionary, this term is characterised as "the act of globalizing": from the noun "global", meaning "pertaining to or involving the whole world", "worldwide" and "universal". In the first volume of Slovník súčasného slovenského jazyka (Dictionary of Contemporary Slovak Language) globalisation is defined as "a global social process (in the economic, political and cultural spheres) which indicates an ever-increasing level of mutual interconnection and dependency of various parts of the world" (SLOVNÍK SÚČASNÉHO SLOVENSKÉHO JAZYKA. A-G 2006, p. 1075). Its characteristic feature is the "breaking down" of time and space, where electronic communication eliminates geographic balance and unites the world through the creation of the "global village" because "the medium is the message" (McLuHAN 1962).

The International Monetary Fund describes globalisation as "a historical process, the result of human innovation and technological progress", and it defines four aspects of globalisation: trade, capital movement, the movement of people and the spread of knowledge (and technology). The World Trade Organisation defines globalisation "as a historical stage of accelerated expansion of market capitalism, like the one experienced in the $19^{\text {th }}$ century with the industrial revolution. It is a fundamental transformation in societies because of the recent technological revolution which has led to a recombining of the economic and social forces on a new territorial dimension" (LAMY 2006). The New York Times pointed out in an article published on 27 July 2007 that globalisation should be governed by governments representing their people (nations) and the planet rather than by corporate empires merely following their own short-term interests (OXford English Dictionary).

Globalisation is closely connected to the idea of glocalisation, which, according to the Oxford Dictionary, comes from the blending of the words global and localisation, and which refers to "the practice of conducting business according to both local and global considerations". This term was firstly used at the end of the 1980s by Japanese economists writing in the Harvard Business Review. In the 1990s, the term was popularised by the British sociologist RoBERTSON and the Canadian sociologists HAMPTON and WELLMAN.

Building on The Oxford Dictionary of New Words (1991), RoBERTSON (1995, p. 28) explains that the word glocalisation has its origin in Japanese business jargon. ROBERTSON states that part of the globalisation occurring today is glocalisation, which he understands as a new outcome of local conditions toward global pressures. HAMPTON and Wellman used the term glocalisation when defining people who actively took part in "both local and wider-ranging activities of friendship, kinship and commerce" (Terminology Coordination Unit). In the Business Dictionary, glocalisation refers to "products or services to benefit a local market while at the same time being developed and distributed on a global level".

This article considers glocalisation to be both the ability to combine the dimensions of the global, national, regional and local, and the ability to understand 
the mutual context and cotext coexistence. "The central project of glocalization is to understand the reconfiguration of locality and local subjects, to account for new cultural forms emerging at the intersection of the global and local [...] Glocalization is a recognition that when ideas, objects, institutions, images, practices and performances, are transplanted to other places, they both bear the marks of history as well as undergo a process of cultural translation." (RAO 2010, p. 5)

\section{Linguistic globalisation and glocalisation}

Language is the most natural, complex and elaborated form of human communication. It is connected to human civilisation and lives and develops alongside it. As a system, language exists in both the individual and social consciousness, and people are its creators and bearers. Any changes in people's lives and in society are inevitably reflected in language.

Globalisation influences every aspect of human life, including language; new culturally defined elements are transferred from one nation to another. In this sense, one can also talk of the "globalisation of language" as the penetration of new linguistic elements on linguistic levels.

For a number of decades, the relationship between linguistic globalisation and English has intensified. For many people, English is the lingua franca of globalisation and the universal symbol of language globalisation. According to CRYSTAL (2003, p. 3), "a language achieves a genuinely global status when it develops a special role that is recognized in every country". GRADDOL (1997) stated that economic globalisation triggered the global expansion of English, which has reciprocally stimulated globalisation. In a further publication, GRADDOL asserts that English "is a phenomenon which lies at the heart of globalization: English is now redefining national and individual identities worldwide; shifting political fault lines; creating new global patterns of wealth and social exclusion; and suggesting new notions of human rights and responsibilities of citizenship" (GRADDOL 2006, p. 12).

The Slovak linguist DoLNík considers the expansion of Anglicisms from two perspectives: as a linguistic movement in an international context and the latest indication of linguistic internationalisation, and as something which "raises the question of how this process will affect national languages” (DolNík 2010, p. 64). „While it is possible to envisage different reactions to and interpretations of this phenomenon, it is virtually impossible to deny that, especially in the past decade, English has permeated all means of communication and expression globally. It is the language of global economy and commerce, of modern technology and the Internet, the default language of science. More importantly, perhaps, English is the standard means whereby people choose to communicate with other people all over the world." (SIFAKIs 2012, p. 475) 
English's current standing as a global language was primarily due to the fact that "English [...] was 'in the right place at the right time"" (CRYSTAL 2003, p. 10). However, the dominance of English is not simply due to its power in the political and economic world, or to it being "in the right place at the right time". To a great extent, it is connected with its influence in the media and cultural spheres and its linguistic form. English is the lingua franca of the Internet: many songs in English, social network statuses and media texts and commentaries written in English spread at the speed of light.

From a linguistic point of view, the universality of English is significant; this is due to its typological character because its analytical principles, as opposed to agglutinative ones, are present as base elements in all other types of languages. The universality of English can be seen in its lexical morphology and grammar. (From a phonetic point of view, however, English is quite specific and can be difficult for a nonnative speaker.) The universality of English is accentuated by the nominal categories of gender, number and case, which are largely absent in the language, as well as conversion (which functions alongside word order), and a lot of words and prefixes of Greek and Latin origin. Conversion in English is one of the most common principles of creating new meanings and word types in a living text. Note for comparison the English word black in the meanings 'a black man', 'black shoes' and 'to blacken', and their Slovak equivalents černoch, čierne topánky, začiernit'/zatemnit'; or the English words Oxford and Oxford Dictionary and the Slovak Oxford, Oxfordský slovnik. In comparison to a lot of languages (even artificial ones), English is more accessible in terms of grammar because its sentence syntax is not always bound by the congruence of grammatical gender and case (e.g. the English phrases my new book and my new books as opposed to the Slovak equivalents moja nová kniha and moje nové knihy), and it has a relatively fixed sentence structure in which the words are ordered according to their emergence in the thought process.

Linguistic globalisation has an influence on language policy and practice as does the effort to preserve national and regional specifics in languages. Even though English is considered to be the lingua franca of globalisation, its worldwide expansion has 'enriched' it with new and local elements with the emergence of local variants of English. At the same time, English has enriched other languages with new linguistic elements from its own system. While British Standard English, American Standard English and Australian Standard English are well known on an everyday level, English today is an international global language with many local varieties. Today English has become the lingua franca of glocalisation, and there is no longer just one form of correct or appropriate English. It is quite true that "the English language has been globalized, has become the world's leading language, but at the same time it is being localized" (SCHNEIDER 2011, pp. 229-230). The glocalisation of English only confirms ROBERTSON's thoughts that glocalisation is a part of globalisation and that linguistic glocalisation is a part of linguistic globalisation. GORTER, a research professor at the University of the Basque Country-Ikerbasque and a specialist on minority language 
education, the linguistic landscape and multilingualism, has said: "Glocalization refers to the ability to combine the dimensions of the global, regional and local. Slogan: 'Think global, act local' converts to: 'Speak global and speak local'" (www.soAs. AC.UK). Indeed, one might add "speak glocal as well."

The line between linguistic globalisation and linguistic glocalisation is very thin. A globalised word which for one language user seems natural can present an impermissible infiltration of foreign elements into the mother tongue for another. On this matter, BASTARDAS-BOADA $(2004$, p. 6) states that "everything that a local language can do, need not be done by a more global language". In linguistic practice, this means that if there already exist local terms for a factual reality then there is no need to use globalising words in their place. On the other hand, new words enrich a language's vocabulary and offer language users a range of synonyms when naming things. Furthermore, their use is characteristic for certain social groups; for instance, Slovak teenagers have a tendency to use English words even when speaking in Slovak.

Linguistic glocalisation is a process of adapting foreign words into the target language and of the ability of a language to connect global elements with domestic ones. In practice this means that the language user automatically brings new words into the grammatical system of his mother tongue; in Slovak this means that new words are automatically categorised into gender and inflected, being given the appropriate gender and case suffixes. Furthermore, the language user creates multiple parts of speech from new words. Linguistic glocalisation requires the coexistence and upholding of two basic linguistic principles: (1) the principle of the linguistic stability of the 'local' language, which will secure its future development; and (2) the principle of linguistic freedom, which will allow the language user to choose from a range of alternatives, i.e. using a local word or a foreign word, which is globally understood along with the relevant signs of adaptation into the linguistic system of the user's mother tongue (a glocal word).

\section{Slovak and the EU}

Slovak is the official language of the Slovak Republic, and from May 2004 it has been one of the 24 official languages of the EU. Around five and a half million inhabitants in Slovakia speak Slovak, as do more than a million people living in the United States. Within EU countries, over 300,000 people speak Slovak in Czechia ${ }^{1}$, as

\footnotetext{
1 As a point of interest and to illustrate the wide intelligibility of Slovak, it is useful to point out that the legal system of Czechia allows for the use of Slovak in official and legal matters without the use of a translator or interpreter. The Administrative Procedure Code (Act No. 500/2004 Coll.) states the following: "The Czech language shall be the language of proceedings for both written filings and oral hearings. Participants in the proceedings may also use the Slovak language for oral hearings and filings in writing." (sec 16, para. 1)
} 
do over 100,000 people in Hungary. Smaller groups of Slovak speakers can be found in other EU countries such as Austria, Belgium, Bulgaria, Croatia, Cyprus, Denmark, Finland, France, Germany, Italy, the Netherlands, Poland, Romania, Sweden, and the United Kingdom. Outside the EU there are Slovak speakers in countries such as Norway, Switzerland, Russia, Ukraine, Israel, Canada, Argentina, Brazil, Uruguay, South Africa, Australia, and New Zealand. Furthermore, Slovak is considered to be the “"Esperanto' of all the Slavic languages due to its most comprehensible character for other users of Slavic languages" (ŠImkoví et al. 2012, p. 47).

In addition to Slovaks, foreigners in Slovakia study Slovak as a part of their university education and on a number of summer language courses: the oldest of these is the Studia Academica Slovaca summer school of Slovak language and culture. In the 50 years of its existence (it was established in 1965) 6,300 students from all continents have completed the course. Lectureships in Slovak language and culture at departments of Slavic languages at universities outside Slovakia are another important aspect of teaching Slovak to foreign students. These positions have been established under international agreements between the Ministry of Education, Science, Research and Sports of the Slovak Republic and education authorities in other countries as well as under direct agreements with foreign universities. Within the EU, there are Slovak lectureships at three universities in Germany, three in Poland, two in Bulgaria, two in Hungary, two in France, and at one university each in Austria, Croatia, Italy, Romania and Slovenia. At these universities, Slovak can be studied at bachelor's, master's and sometimes at doctoral level. Most students of Slovak are based in Slavic-speaking countries and in places where there is a sizable Slovak minority. The present author's own experiences at the Department of Slavonic Studies at the University of Vienna [Wien] have suggested that Slovak is a favourite choice of a second Slavic language among students. In addition, the Ministry of Education, Science, Research and Sports of the Slovak Republic has been sending primary and secondary school teachers abroad to bilingual schools where Slovak is a language of tuition and schools where Slovak is taught as a subject for a considerable amount of time.

It is important to stress that the summer schools of Slovak language and culture and lectureships in Slovak language were established at universities abroad (regardless of whether these universities were in the former Eastern or Western Bloc) before Slovakia joined the EU. The creation of new lectureships and the restructuring of others were influenced by the Velvet Revolution in November 1989 and particularly by the establishment of Slovakia as an independent state in 1993.

The above suggests that the accession of Slovakia to the EU did not have a noticeable impact on Slovak language tuition in Slovakia or abroad, but it did leave its mark in a linguistic sense, particularly in terms of lexis. Under the influence of linguistic globalisation, the Slovak language was enriched with new words, which were related to the integration of European countries and the unification of rights and laws within EU member states. 
Shortly after Slovakia's accession to the EU, the Slovak language experienced an explosion in new words featuring the prefix euro-: for example, euroagenda (Euro-agenda), eurobyrokracia (Euro-bureaucracy), eurocent (Euro cent), eurocity (EuroCity), eurodolár (Eurodollar), eurofil (europhile), eurofób (europhobe), eurofond (EU fund), eurogrant (EU grant), eurokalkulačka (Euro calculator), eurokarta (a card valid throughout the EU), eurokomisár (European Commissioner), eurokomunizmus (eurocommunism), eurokrat (eurocrat), euroliga (euroleague), euromanažér (euromanager), euromanažment (euro-management), euronorma (euro-norm), euroobligácia (eurobond), eurooptimista (euro-optimist), europarlament (the European Parliament), europeizmus (europeism), europeniaze (euro-money), europesimista (euro-pessimist), europlatba (europayment), europolitik (EU politician), europolitika (europolitics) and eurozóna (Eurozone). The majority of such words are regularly used in all linguistic styles, and a lot of them would be easily understood without a translation being necessary. In Slovak it is possible to create different parts of speech from these words in accordance with the rules of the linguistic system: e.g. eurooptimizmus - eurooptimista - eurooptimistka - eurooptimistický (euro-optimism - euro-optimist [male] - eurooptimist [female] - euro-optimistic).

The vocabulary of Slovak has been enriched by 'euro-denominations', which are not readily understandable: e.g. euromena (Euro-currency), euroobal (A4 page protector), euroobčan (EU citizen), eurookno ('Euro-window' [a wooden window fulfilling European norms]), europeniaze (money from EU funds), europoslanec (Member of the European Parliament [MEP]). The grammatical system of Slovak allows for further parts of speech to be created from these words: e.g. euromena euromenový (Euro-currency [as a noun] - Euro-currency [as an adjective]) and europoslanec - europoslankyňa - europoslanecký (male MEP - female MEP - MEP [as an adjective]). This sort of change took place in other languages as other nation states became EU members, and Slovak did not differ from languages in other member states in this regard.

\section{Globalisation and glocalisation of Slovak}

Slovak is a moderately open language, which means that new linguistic elements are added to its system as a result of contact with other languages. These additions are followed closely by linguists, who adapt them to Slovak norms. In connection with the reception of new elements, Slovak linguists have mentioned the following terms: foreign words (Mistrík 1988), dynamics of vocabulary (HoRecký, BuZÁssyová, Bosák et al. 1989), international, foreign words (MistRík 1993), reception of expressions (DoLNíK 1999), movements in lexis (Šıмкоvá 1999), penetration of foreign linguistic elements (TIBENSKÁ 2007), communicative penetration (BöHMEROVÁ 2012) and the globalisation and glocalisation of language (ŠKKVARENINOVÁ 2015). 27 years ago, Mistrík (1988, p. 
50) asserted that "Slovak contains ... received words from over 30 languages"; some 24 years later, Dudok (2012, p. 264) mentioned "more than one hundred languages ... which have contributed towards the development of Slovak". Slovak is a language, which has been relatively open to the reception of internationalisms (ONDREJOVIČ 1999) and their adaptation into its grammatical system.

The internationalisation of Slovak and the acquisition of foreign words into the language made a notable appearance in the 1990s, when Slovakia underwent sociopolitical change and became an independent state. In the 1990s, Slovak experienced "a large expansion of English linguistic elements" (TiBenská 2007, p. 146). A large number of Anglicisms such as clearing (clearing), leasing (leasing), bilboard (billboard), databáza (database), eutanázia (euthanasia), delimitovat' (delimitate), medializácia (publicity/media attention), destabilizácia (destabilisation), demonopolizácia (demonopolisation), lobista (lobbyist), bos (boss) and kouč (coach) entered the language. The intensity of life, global communication and technological advancements have all inherently led to English having an impact on Slovak because it is a global language. Currently, it is possible to talk of a process of linguistic globalisation taking place rather than one of linguistic internationalisation.

English is the most popular foreign language in Slovakia. Competent users of English find it easier to find work, and English makes communication a lot easier in a number of professions. However, not all Slovak linguists have a positive opinion on the use of English. Some warn about "the mechanical acquisition" of English words and "a lack of exactness in understanding" (HoReckÝ, BuzÁssyová \& Bosák 1989, p. 293); others note the "excessive amount of used English words and phrases" and the "undignified imitation of foreign paradigms" in Slovak (KaČALA \& KRAJČOviČ 2001, p. 103). However, it is necessary to state in this context that "often the situation occurs where [linguists] are fighting against an immediate threat (e.g. Anglicisms) and they lose sight of the fact that these additions to the language are potential or actual Europeisms or internationalisms with a common Greco-Latin origin which have enriched our languages for centuries" (ŠIMKOVÁ 1999, p. 135).

The globalisation and glocalisation of the Slovak language is most apparent in the adaptation of Anglicisms into the Slovak linguistic system; this is most clearly the case with those Anglicisms where there is not a full correspondence between how a word is written and how it sounds. Moreover, when Anglicisms (and other international words) are used in Slovak for a longer period of time, their spelling adapts to the norms of Slovak pronunciation. The globalisation and glocalisation of Slovak can be seen in the gradual adaptation of Anglicisms into Slovak. Initially an Anglicism in Slovak is written with the English spelling, after some time most Anglicisms are then written in an English and a Slovak variant (one with English spelling and the other according to Slovak pronunciation), and eventually the Slovak variant is the sole form left in the language (spelt according to the Slovak logic of 'write it as you hear it'). 
The use of Anglicisms in Slovak, which are only codified in their English form is closely connected to the globalisation of the Slovak language. Their meaning is obvious to anyone competent in English without a translation being necessary. Such English loanwords in Slovak include cheeseburger, boom, comeback, welcome drink, sorry, soft, hard, outfit, outlet, selfie, know-how, call-girl, fashion week, draft, outsider, feeling, holding, tender (in the sense of a bidding process), soccer, workshop, mainstream, comeback, bestseller, selfpromo and VIP. Most of these are neologisms, but the words know-how, sorry, baby, and hello came into Slovak a relatively long time ago. Despite this, these words are still written with their English spelling and they have preserved their English pronunciation. According to TiBEnSKÁ (2007), this is because these words are "used in everyday communication by a wide range of users" (p. 149).

The influence of globalisation on Slovak is also noticeable in the use of compound nouns and multi-word naming units: e.g. standing ovation, home banking, internet banking, call centrum (call centre), help desk, hot line (also translated as horúca linka) and human resources (also translated as l'udské zdroje).

The intermediate stage between the globalisation and glocalisation of Slovak is seen in the spelling variants of Anglicisms: e.g. šou, show; samit, summit; tínedžer, teenager; džez, jazz; and rock, rok/rockový, rokový (denoting 'rock' as an adjective). These variants in the written form of such words occur when there is a noticeable fluctuation in spelling. The order of the variants in terms of their usage indicates their level of domestication. In Slovak there is a tendency to favour the Slovak transliteration over the English original.

The glocalisation of Slovak occurs in those Anglicisms, which were initially written in Slovak in accordance with English spelling, but which in the present day are only written in the domesticated glocalised form corresponding to Slovak pronunciation (the standard spelling of the word in Slovak is given in bold): business/ biznis, boss/bos, handicap/hendikep, leader/líder, clearing/klíring, make up/mejkap, image/imidž,jazz/džez, manchester/menčester and gentleman/džentlmen. The original (English) spelling of these words is no longer in use and is considered to be against the fixed correct spelling. Some glocalised Anglicisms in the codified Krátky slovník slovenského jazyka (Short Dictionary of the Slovak Language) "are presented alongside the domesticated form (in bold) also in their original spelling: e.g. tím, orig. word team; bekhend, orig. word backhand. This happens with words where the process of standard domestication has progressed but where the origin of the word can still be vividly felt (usually this occurs with new internationalisms)" (KRÁTKY SLOVNíK SLOVENSKÉHO JAZYKA 1997, p. 15).

In terms of word formation and morphology, the glocalisation of Slovak can be seen in the adaptation of English neologisms into the Slovak language system through the addition of Slovak derivational and relational morphemes. Such expressions 
include čipsy (chips), draftovat' (to draft), koučovat' (to coach), shareovat' (to share), deletovat' (to delete), skrínovat' (to screen), suportovat' (to support), zalogovat' sa (to log in), odlogovat'sa (to log out), esemeskovat' (to send an SMS), blogovat' (to blog), skypovat'skajpovat' (to use Skype), četovat' (to chat online), pastnút' do četu (to paste into a chat message), kliknút' (to click), sejvnút' (to save), forwardnút' (to forward), začekovat'sa (to check in), poslat' lajky (to send 'likes'), lajknút' na fejsbúku/fejsbuku (to 'like' on Facebook), friendlisty (friend lists), kúlový (cool), apgrejdnutý (upgraded), freestylový (freestyle), osobné feedbacky (personal feedback), requestori (requesters), peoplemetre (people meters), overtimy (overtime), wifina (Wi-Fi), pirsingy (piercings), zabukovat'(to book), streetstylový (street-style), street fashion fotografia (street fashion photography), fashion weeky (fashion weeks), fejky (fakes), topmodelka (top model [female]), šoumenka (entertainer [female]), topky (top news), filling (feeling), lúzer (loser), haker (hacker), spamový (spam [adjective]), webový (web [adjective]).

The use of compound nouns and multi-word naming units, which are calques translated from English are also part of the process of glocalisation in Slovak. For instance, Slovak has the following collocations: l'udské zdroje (human resources), medziludská/interpersonálna komunikácia (interpersonal communication), separovaný zber (separate collection [of waste]), aktivačný poplatok (activation fee), mobilná dátová komunikácia (mobile data communication), verejný záujem (public interest), menová zóna (currency zone), vládny kabinet (Cabinet [government]), nákupné centrum (shopping centre), priemyselný park (industrial park), vzostupný trend (upward trend), obytné satelity (satellite communities), horúca linka (hotline), mimovládna organizácia (non-governmental organisation), obnovitel'né zdroje energie (renewable sources of energy), legislativny priestor (legislative space), jazykový manažment (language management), biznis centrum (business centre), operovanie na trhu (operating in the market), vyslovenie posolstva (pronouncement of the message). Such collocations are used primarily in mass-media communications.

Other highly productive globalisms in Slovak currently include "hybrid polylexical set expressions and structures" (BöHMEROvÁ 2012, p. 282), which emerged as a result of translation from English. They are frequently used in phatic communication and in the media to emphasise expression, for example, vidime sa (we see each other), počujeme sa (we hear each other), voláme si (we call each other). Similarly, wishing someone pekný/prijemný deň (a nice/pleasant day), a phrase often heard at the end of conversations, is an elided translation of the English "Have a nice day". In business communication, calque questions such as Ako vám môžem pomôct?? (from the English How can I help you?) and Čo môžem pre vás urobit? (from the English What can I do for you?) are very common. A lot of young people use these calque questions in place of the traditional Nech sa páči, Čo si želáte? (BöHMERová 2012).

In Slovak, phrases which have been created by translating a future tense from English, such as Idem končit' (I am going to finish) and Idem sa lúcit'(I am going to say goodbye), both of which are translations of the English going-to future construction, 
are becoming more popular than traditional Slovak expressions Končím and Lúčim sa. Expressions used by young people, which have become a part of youth slang, e.g. byt' dead (be dead), byt' kúl/cool (be cool), byt' in (be 'in') and byt' out (be 'out'), can also be categorised within hybrid glocalising polylexical set expressions and structures.

There is no evidence of any particular tension between the global and the local in the glocalisation of Slovak. Rather, glocalisation is perceived as an adaptation of English words to norms of the Slovak language, which from a diachronic point of view is nothing new. The use of hybrid glocalising linguistic elements affirms the tendency of people to make communication more attractive and come across as more striking, conversational, fun, emotional and youthful. Given that Anglicisms can be found in all types of communication and in all styles, one can only confirm the fact that "[language] users know how to handle their presence" (DuDoK 2012, p. 265).

\section{Conclusion}

"Unity in diversity" is the motto of the EU. It calls for respect for the EU's variety of cultures, traditions, faiths and languages, and is part of the EU's Charter of Fundamental Rights, which was signed in 2000. One of the basic elements of the EU's diversity is its multilingualism. In addition to the EU's 24 official and working languages, there are another 60 which are spoken on its territory. All of these languages (as well as non-European ones) can mutually influence each other to varying degrees. For a number of decades, much has been said about the strong influence of English, which has become the lingua franca of globalisation. The phenomenon of linguistic globalisation has affected Slovak, which now receives more words from English than it does from other languages.

Anglicisms in Slovak can be found most often in colloquial language, professional jargon (particularly in the IT sector), youth slang, the media, advertising texts, and business and online communication. These additions to Slovak primarily expand and modify the language's lexical system, which is the most open linguistic subsystem.

The process of linguistic glocalisation takes place with the adaptation of English neologisms into the internal system of Slovak through their transliteration in accordance with Slovak pronunciation and their acquisition of Slovak derivational and relational morphemes. Linguistic glocalisation can also be seen in the use of compound nouns and multi-word naming units, which are calques from English and in the calque translations of English phrases. The use of hybrid glocalising linguistic elements enriches Slovak and contributes to making communication more attractive. It allows for the playful manipulation of the language and the distinction between notional and expressive expression. 
The globalisation and glocalisation of Slovak will certainly continue in the future. Slovak is an adequately developed language with the ability to cope with and adapt to globalising factors by glocalising them into its linguistic system. Slovak is a modern and developed language, which connects global and local linguistic elements, and is correctly considered to be the 'Esperanto' of Slavic languages.

I would like to finish my paper with the words of MAY, a professor at the University of Waikato, Hamilton, New Zealand, who writes on language and education with a particular focus on addressing and accommodating cultural and linguistic diversity: “ "If globalisation can teach us anything, it is that to be a linguistic citizen of the world requires us to not limit our language choice but rather to extend it, so that we can operate fully and effectively in all contexts - the local, national and global." (MAY 2009, p. 58)

\section{References}

Bastardas-Boada A. (2004), Linguistic Sustainability and Language Ecology. In: Language \& Ecology, March 2005, pp. 1-14 < http://www.academia.edu> (accessed 29 November 2014)

BöHMEROvÁ A. (2012), Zjavné i menej zjavné prieniky anglických nadslovných javov a štruktúr do súčasnej slovenčiny. In: BoHUnickÁ A. (ed.), Jazykoveda v pohybe, pp. 281-292. Bratislava, Univerzita Komenského.

Business Dictionary < http://www.businessdictionary.com> (accessed 12 February 2015)

Crystal D. (2001), Language and the Internet. Cambridge, Cambridge University Press.

Crystal D. (2003), English as a Global Language. Cambridge, Cambridge University.

Dolník J. (1999), Preberanie výrazov a kultivovanie spisovného jazyka. In: BosÁk J. (ed.), Internacionalizácia v súčasných slovanských jazykoch: za a proti, pp. 75-79. Bratislava, Veda.

Dolník J. (2010), Teória spisovného jazyka so zretel’om na spisovnú slovenčinu. Bratislava, Veda.

Dudok M. (2012), Aktualizácia cudzích slov v medzijazykovej komunikácii. In: BoHUNICKÁ A. (ed.), Jazykoveda v pohybe, pp. 264-273. Bratislava, Univerzita Komenského,

Gorter D., Glocalization and sustainable linguistic diversity $<\mathrm{https}$ ://www.soas.ac.uk $>$ (accessed 20 November 2014)

Graddol D. (1997), The future of English? London, British Council.

Graddol D. (2006), English next. London, British Council.

HoreckÝ J., BuzÁssyová K., Bosák J. et al. (1989), Dynamika slovnej zásoby súčasnej slovenčiny. Bratislava, Veda.

International Monetary Fund (ed.) (2000), Globalization: Threats or Opportunity $<$ http:// www.imf.org/external $>$ (accessed 11 February 2015)

KaČAla J., KrajČoviČ R. (2001), Náčrt dejín spisovnej slovenčiny. Bratislava, PF UK.

KRÁTKY SLOVNÍK SLOVENSKÉHO JAZYKA (1997), Bratislava, Veda. 
Lamy P. (2006), Humanising globalization. Geneva, Switzerland, The WTO <http://www.wto. org/english/news> (accessed 1 June 2011)

MAY S. (2009), Language Rights: Linking the Local and the Global. In: STARK C. (ed.), Globalization \& Languages: Building on Our Rich Heritage, pp. 52-58. France, UNESCO.

McLuhan M. (1962), The Gutenberg Galaxy: The Making of Typographic Man. University of Toronto Press.

Ministry of Culture of the Slovak Republic <http://www.culture.gov.sk> (accessed 20 February 2015)

MistRík J. (1988), Moderná slovenčina. Bratislava, Slovenské pedagogické nakladatel'stvo.

Mistrík J. (ed.) (1993), Encyklopédia jazykovedy. Bratislava, Obzor.

ONDREJOVIČ S. (1999), O postojoch k internacionalizmom. In: BosÁK J. (ed.), Internacionalizácia v súčasných slovanských jazykoch: za a proti, pp. 83-87. Bratislava, Veda.

OXford English Dictionary < http://www.oed.com> (accessed 12 November 2014)

OXFORD DictionARY <http://www.oxforddictionaries.com> (accessed 12 November 2014)

Rao S. (2010), "I Need an Indian Touch": Glocalization and Bollywood Films. In: Journal of International and Intercultural Communication, 3, 1, pp. 1-19.

Robertson R. (1995), Glocalization: Time-Space and Homogeneity-Heterogeneity. In: Featherston M., Lash S., Robertson R. (eds.), Global Modernities, pp. 25-44. London, Sage.

SchneIDER E.W. (2011), English around the world: An introduction. Cambridge, Cambridge University Press.

Sharma Ch.K. (2009), Emerging Dimensions of Decentralisation Debate in the Age of Globalisation. In: Indian Journal of Federal Studies, 19, 1, pp. 47-65.

SIFAKIS N.C. (2012), The English Language and Globalisation: Aspects of Contemporary Reality in Greece, Europe, and the Rest of the World. Athens, Herodots.

SLOVNÍK SÚČASNÉHO SLOVENSKÉHO JAZYKA. A-G. (2006), Bratislava, Veda.

ŠAling S., IvanovÁ-ŠAlingová M., Maníková Z. (1997a), Vel'ký slovník cudzích slov. Bratislava - Vel'ký Šariš, Vydavatel'stvo SAMO.

Šaling S., Ivanová-ŠAlingová M., Maníková Z. (1997b), Slovník cudzích slov pre školu a prax. Prešov, Vydavatel'stvo SAMO.

ŠImková M. (1999), Pohyby v slovenskej lexike. In: BosÁK J. (ed.), Internacionalizácia v súčasných slovanských jazykoch: za a proti, pp. 116-136. Bratislava, Veda.

ŠımкovÁ M. et al. (2012), Slovenský jazyk v digitálnom veku: The Slovak Language in the Digital Age. Berlin - New York, Springer.

ŠKVARENINOVÁ O. (2015), Vplyv médií na globalizáciu slovenského jazyka. In: WACHTARCZYKovÁ J., SATINSKÁ L., ONDREJOvič S. (eds.), Jazyk v politických, ideologických a interkultúrnych vzt'ahoch (= Sociolinguistica Slovaca, 8), pp. 33-47. Bratislava, Veda.

Terminology Coordination Unit <https://termcoord.wordpress.com> (accessed 12 February 2015)

Tibenská E. (2007), Prenikanie cudzích jazykových prvkov do slovenčiny. In: PekARovičová J., Vojtech M. (eds.), Studia Academica Slovaca, 36, pp. 139-155. Bratislava, Stimul.

VÉPYOVÁ Z. (2012), Internetový slang v modernej slovenčine. In: HLAvŇOVÁ A., JanČOvičovÁ L., BÉRešová J. (eds.), Integrating Language, Literature and Culture in ELT, pp. 74-78. Trnava, Trnavská univerzita v Trnave. 